\title{
Branched-chain Sugars. XXIX. Synthesis of Moenuronic Acid (4-C-Methyl-D-glucuronic Acid) $)^{1)}$
}

\author{
Ken-ichi Sato, Kazusuke Kubo, Namgi Hong, Hisashi Kodama, \\ and Juji Yoshrmura* \\ Laboratory of Chemistry for Natural Products, Faculty of Science, Tokyo Institute of Technology, \\ Nagatsuta, Midori-ku, Yokohama 227 \\ (Received September 18, 1981)
}

\begin{abstract}
Moenuronic acid (4- $C$-methyl-D-glucuronic acid), a branched-chain sugar component of moenomycin A, was synthesized by the introduction of an axial $C$-methyl group into methyl 2,3-di- $O$-benzyl-6- $O$-trityl- $\alpha$-D-xylohexopyranosid-4-ulose by the reaction with methyllithium, followed by deprotection and platinum-catalyzed oxidation of the $C$-6 position. Stereoselectivities in a few reactions for the introduction of $C$-methyl group were examined.
\end{abstract}

Moenomycin $\mathrm{A}^{2)}$ is a phosphoglycolipid antibiotic, which inhibits strongly the formation of linear polysaccharide-chain of murein from disaccharide intermediates $^{3}$ ) in the cell-wall biosynthesis. A new brancehdchain uronic acid called moenuronic acid $(\mathbf{1} ; 4-C$ methyl-D-glucuronic acid) was found as a component. ${ }^{4}$ By the ethanolysis of moenomycin $A$, the moiety was isolated as the corresponding ethyl $\beta$-D-glucofuranosidurono-6,3-lactone (2), and the structure was determined by the IR, NMR, CD, and mass spectroscopic data of $\mathbf{2}$ and its diacetate (3).5) This paper describes the first syn thesis of $\mathbf{3}$.

\section{Results and Discussion}

The introduction of an axial $C$-methyl group to the $C$-4 position of a D-xylo-hexopyranosid-4-ulose and the following oxidation of $C-6$ position of the product are necessary for the synthesis of $\mathbf{1}$.

For the former problem, a few pathways from ben$\mathrm{zyl}^{6}{ }^{6}$ and methyl 2,3-di-O-benzyl-6-O-trityl- $\alpha$-D- $x y l o-$ hexopyranosid-4-uloses (4 and 5) and 4- $C$-methylene derivative (6) of 5 were examined. Compound 5 was synthesized by the oxidation of methyl 2,3-di$O$-benzyl-6- $O$-trityl- $\alpha$-D-glucopyranoside ${ }^{7}$ with dimethyl sulfoxide-trifluoroacetic anhydride in quantitative yield. Compound 6 was obtained in $63 \%$ yield by the usual Wittig reaction of $\mathbf{5}$.

It is known that the reaction of $\alpha-D-x y l o$-hexopyranosid-4-uloses $^{8)}$ or a $\alpha$-L-threo-pentopyranosid-4-ulose ${ }^{9}$ ) with methyllithium at a low temperature gives axial $C$-methyl derivatives, whereas that with methylmagnesium iodide affords equatorial $C$-methyl derivatives predominantly. Therefore, these reactions of $\mathbf{4}$ and 5 were examined at first. As shown in Table 1, reaction of 4 with methyllithium at $-78^{\circ} \mathrm{C}$ in ether gave exclusively the axial attack product (7), while that with methylmagnesium iodide in ether at $-78^{\circ} \mathrm{G}$ gave only the equatorial attack product $(\mathbf{8})$. The Grignard reaction in ether-tetrahydrofuran $(1: 1)$ under reflux gave 7 and 8 in the ratio of 1 to 1 . A similar tendency was also observed in the reaction of $\mathbf{5}$, and the corresponding $C$-methyl derivatives (9 and 10) were obtained. Configuration of $\mathbf{7}-\mathbf{1 0}$ was determined from the chemical shifts of axially (7: $\delta 15.79$ ppm, 9: $\delta 14.92 \mathrm{ppm}$ ) and equatorially (8: $\delta 22.03$ ppm, 10: $\delta 22.02 \mathrm{ppm}$ ) oriented $C$-methyl carbons in ${ }^{13} \mathrm{C}-\mathrm{NMR}$ spectra. ${ }^{8-10)}$

On the other hand, diazomethane reaction ${ }^{11)}$ of 4 and 5 gave one epimer of the corresponding spiro epoxides (11 and 12) in 20 and $15 \%$ yields, respectively, together with larger amount of ring-expanded products (13 and 14). The structures of 13 and 14 were throughly proved by the ${ }^{1} \mathrm{H}$-NMR spectra (see Experimental). While, epoxidation ${ }^{12}$ ) of 6 with $m$ chloroperbenzoic acid gave a 1:1 mixture of the corresponding spiro epoxides (12 and $\mathbf{1 5}$ ) in $80 \%$ yield. Reduction of 11, 12, and $\mathbf{1 5}$ with lithium aluminium hydride gave 7,9 , and 10 in fairly good yields, respectively. From these facts, configurations of 11, 12,

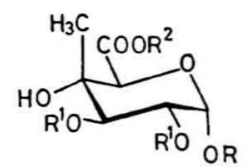

(1) $R=R^{1}=R^{2}=H$ (20) $R=M e, R^{1}=R^{2}=H$ (21) $R=M e, R^{1}=A c, R^{2}=E t$

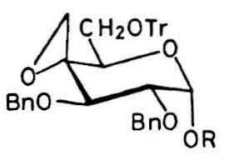

(11) $R=B n$

(12) $R=M e$

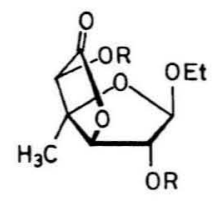

(2) $\mathrm{R}=\mathrm{H}$

(3) $\mathrm{R}=\mathrm{AC}$

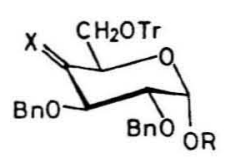

(4) $\mathrm{R}=\mathrm{Bn}, \mathrm{X}=0$

(5) $R=M e, X=0$

(6) $\mathrm{R}=\mathrm{Me}, \mathrm{X}=\mathrm{CH}_{2}$

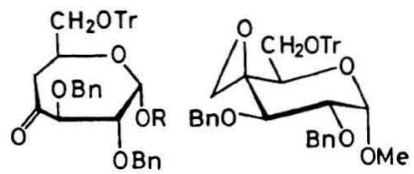

(13) $\mathrm{R}=\mathrm{Bn}$

(14) $\mathrm{R}=\mathrm{Me}$

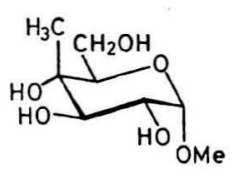

(19)

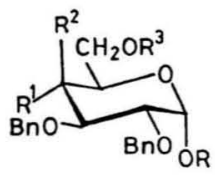

R $R^{1} R^{2} \quad R^{3}$

(7) $\mathrm{Bn} \mathrm{OH} \mathrm{Me} \mathrm{Tr}$

(8) $\mathrm{Bn} \mathrm{Me} \mathrm{OH} \mathrm{Tr}$

(9) $\mathrm{Me} \mathrm{OH} \mathrm{Me} \mathrm{Tr}$

(10) $\mathrm{Me} \mathrm{Me} \mathrm{OH} \mathrm{Tr}$

(16) $\mathrm{Bn} \mathrm{OH} \mathrm{Me} \mathrm{H}$

(17) $\mathrm{Bn} \mathrm{Me} \mathrm{OH} \mathrm{H}$

(18) $\mathrm{Me} \mathrm{OH} \mathrm{Me} \mathrm{H}$

$B n=$ benzy Tr = trityl 
TABle 1. Comparison OF STEREOSELEGTIVITIES IN THE REACTIONS FOR THE INTRODUGTION OF A 4-C-METHYL GROUP INTO 4-6

\begin{tabular}{|c|c|c|c|c|c|c|c|c|}
\hline \multirow{2}{*}{ Substrate } & \multirow{2}{*}{ Reagent } & \multicolumn{2}{|c|}{ Conditions } & \multirow{2}{*}{\multicolumn{4}{|c|}{$\begin{array}{l}\text { Ratio of products } \\
\text { axial : equatorial attack }\end{array}$}} & \multirow{2}{*}{ Yield $/ \%$} \\
\hline & & Solvent & $\operatorname{Temp} /{ }^{\circ} \mathrm{C}$ & & & & & \\
\hline 4 & $\begin{array}{l}\mathrm{CH}_{3} \mathrm{Li} \\
\mathrm{CH}_{3} \mathrm{MgI} \\
\mathrm{CH}_{3} \mathrm{MgI}\end{array}$ & $\begin{array}{l}\text { Ether } \\
\text { Ether } \\
\text { Ether-THF }\end{array}$ & $\begin{array}{l}-78 \\
-78 \\
\text { Boiling }\end{array}$ & $\begin{array}{l}\text { (7) } \\
(7)\end{array}$ & $\begin{array}{l}1 \\
0 \\
1\end{array}$ & 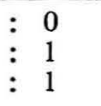 & $\begin{array}{l}(8) \\
(8)\end{array}$ & $\begin{array}{l}58 \\
84 \\
72\end{array}$ \\
\hline 5 & $\begin{array}{l}\mathrm{CH}_{3} \mathrm{Li} \\
\mathrm{CH}_{3} \mathrm{MgI} \\
\mathrm{CH}_{3} \mathrm{MgI}\end{array}$ & $\begin{array}{l}\text { Ether } \\
\text { Ether } \\
\text { Ether }\end{array}$ & $\begin{array}{r}-78 \\
-78 \\
\mathrm{RT}\end{array}$ & $\begin{array}{l}(9) \\
(9)\end{array}$ & $\begin{array}{l}1 \\
0 \\
1\end{array}$ & $\begin{array}{l}: 0 \\
: 1 \\
: 2.2\end{array}$ & $\begin{array}{l}(\mathbf{1 0}) \\
(\mathbf{1 0})\end{array}$ & $\begin{array}{l}95 \\
84 \\
93\end{array}$ \\
\hline 4 & $\mathrm{CH}_{2} \mathrm{~N}_{2}$ & Ethanol & $\mathrm{RT}$ & (11) & 1 & $: 0$ & & 20 \\
\hline 5 & $\mathrm{CH}_{2} \mathrm{~N}_{2}$ & Ethanol & $\mathrm{RT}$ & (12) & 1 & $: 0$ & & 15 \\
\hline 6 & $m-\mathrm{ClC}_{6} \mathrm{H}_{4} \mathrm{CO}_{3} \mathrm{H}$ & $\mathrm{CH}_{2} \mathrm{Cl}_{2}$ & $\mathrm{RT}$ & (12) & 1 & $: 1$ & (15) & 81 \\
\hline
\end{tabular}

TABle 2. Physical CONSTANTs of 4- $C$-Methyl-D-glucuronic acid DeRIVAtives

\begin{tabular}{|c|c|c|c|c|c|c|c|c|c|c|c|}
\hline \multirow[b]{2}{*}{ Derivatives } & \multirow{2}{*}{$\frac{[\alpha]_{D}{ }^{a)}}{\circ}$} & \multicolumn{9}{|c|}{ Chemical shifts $(\delta)$ and coupling constants $(\mathrm{Hz})^{\mathrm{b})}$} & \multirow[b]{2}{*}{$\frac{v_{\mathrm{C}=0}}{\mathrm{~cm}^{-1}}$} \\
\hline & & $\begin{array}{l}\mathrm{H}-1 \\
\left(J_{1,2}\right)\end{array}$ & $\begin{array}{l}\mathrm{H}-2 \\
\left(J_{2,3}\right)\end{array}$ & H-3 & H-5 & 4- $\mathrm{CH}_{3}$ & OAc & $\begin{array}{l}\mathrm{OCH}_{2} \\
\left(J_{\mathrm{g} \oplus \mathrm{m}}\right)\end{array}$ & $\begin{array}{c}\mathrm{CH}_{3} \\
\left(J_{\mathrm{CH}_{2}, \mathrm{CH}_{3}}\right)\end{array}$ & $\mathrm{OMe}$ & \\
\hline 2 & -47.6 & $5.14 \mathrm{~s}$ & $4.41 \mathrm{~s}$ & $4.60 \mathrm{~s}$ & $4.16 \mathrm{~s}$ & $1.67 \mathrm{~s}$ & - & $\begin{array}{l}3.74 \mathrm{dq}, 3.56 \mathrm{dq} \\
(9.0)\end{array}$ & $\begin{array}{l}1.18 \mathrm{t} \\
(7.0)\end{array}$ & - & 1790 \\
\hline 3 & +55.4 & $5.12 \mathrm{~s}$ & $5.42 \mathrm{~s}$ & $4.62 \mathrm{~s}$ & $5.17 \mathrm{~s}$ & $1.63 \mathrm{~s}$ & $\begin{array}{l}2.24 \mathrm{~s} \\
2.13 \mathrm{~s}\end{array}$ & $\begin{array}{l}3.86 \mathrm{dq}, 3.45 \mathrm{dq} \\
(9.0)\end{array}$ & $\begin{array}{l}1.18 \mathrm{t} \\
(7.0)\end{array}$ & - & $\begin{array}{l}1810 \\
1750\end{array}$ \\
\hline$\stackrel{3}{(\text { reported) }}$ & - & $5.14 \mathrm{~s}$ & $5.42 \mathrm{~s}$ & $4.60 \mathrm{~s}$ & $5.19 \mathrm{~s}$ & $1.63 \mathrm{~s}$ & $\begin{array}{l}2.25 \mathrm{~s} \\
2.13 \mathrm{~s}\end{array}$ & $3.70 \mathrm{~m}$ & $1.19 \mathrm{t}$ & - & $\begin{array}{l}1810 \\
1750\end{array}$ \\
\hline 20 & +87.0 & $\begin{array}{l}4.77 \mathrm{~d} \\
(4.0)\end{array}$ & $\begin{array}{l}3.43 \mathrm{dd} \\
(10.5)\end{array}$ & $3.74 \mathrm{~d}$ & $4.19 \mathrm{~s}$ & $1.18 \mathrm{~s}$ & - & - & - & $3.43 \mathrm{~s}$ & 1730 \\
\hline 21 & +112 & $\begin{array}{l}5.03 \mathrm{~d} \\
(3.4)\end{array}$ & $\begin{array}{l}4.77 \mathrm{dd} \\
(10.4)\end{array}$ & $5.41 \mathrm{~d}$ & $4.37 \mathrm{~s}$ & $1.30 \mathrm{~s}$ & $\begin{array}{l}2.12 \mathrm{~s} \\
2.07 \mathrm{~s}\end{array}$ & $4.30 \mathrm{q}$ & $\begin{array}{l}1.35 \mathrm{t} \\
(6.8)\end{array}$ & $3.44 \mathrm{~s}$ & 1730 \\
\hline$\stackrel{22}{\text { (reported) }}$ & - & $\begin{array}{l}5.63 \mathrm{dd} \\
(3.5)\end{array}$ & $\begin{array}{l}3.81 \mathrm{~m} \\
(10.4)\end{array}$ & $5.00 \mathrm{~d}$ & $4.48 \mathrm{~s}$ & $1.25 \mathrm{~s}$ & - & - & - & - & - \\
\hline
\end{tabular}

a) The rotational values of $\mathbf{2}$ and $\mathbf{2 0}$ were measured in ethanol and methanol, respectively. b) ${ }^{1} \mathrm{H}-\mathrm{NMR}$ spectrum

of $\mathbf{2 0}$ was taken in methanol-d. The spectrum of 2 showed signal of hydroxyl protons at $\delta 2.90 \mathrm{bs}$.

and 15 were established. Peroxy acid oxidation of methylene derivative such as $\mathbf{6}$ usually proceeds unselectively, ${ }^{12)}$ and the selectivities in the reaction of 4-uloses with methyllithium or diazomethane will be discussed in detail in the following papers.

For the oxidation of $C-6$ position, $7-9$ were partially hydrolyzed with $70 \%$ acetic acid to give the corresponding de- $O$-tritylated products $(\mathbf{1 6}-\mathbf{1 8})$, respectively. However, attempted oxidation of $\mathbf{1 6}$ and $\mathbf{1 7}$ with chromium trioxide, ${ }^{13)}$ potassium permanganate, ${ }^{14)}$ and oxygen-platinum ${ }^{15}$ ) gave commonly complex results, accompanying with the oxidation of the benzyl groups. ${ }^{6,16)}$ Therefore, $O$-benzyl groups of 18 were previously removed by hydrogenolysis to give methyl 4- $C$-methyl- $\alpha$-D-glucopyranoside (19) in quantitative yield. Oxidation of $\mathbf{1 9}$ in slightly alkaline aqueous solution with oxygen in the presence of platinumcarbon gave the corresponding glucuronic acid (20) in $86 \%$ yield. Treatment of $\mathbf{2 0}$ with $0.1 \mathrm{M}$ ethanolic hydrogen chloride for $16 \mathrm{~h}$ under reflux, and then base-catalyzed acetylation of the products gave $\mathbf{3}$ and methyl 2,3-di- $O$-acetyl-4- $C$-methyl- $\alpha$-D-glucopyranosiduronic acid ethyl ester (21) in 28 and $55 \%$ yields, respectively. The formation of $\mathbf{2 1}$ implies the incomplete ethanolysis of the glycoside linkage of $\mathbf{2 0}$. A similar ethanolysis of $\mathbf{2 1}$ for $\mathbf{3}$ d gave $\mathbf{2}$ in quantitative yield. Physical constants of 4-C-methyl-D-glucuronic acid derivatives were summarized in Table 2, together with those of 3-O-carbamoyl-1-phosphate derivative (22) of 1 , obtained by hydrolysis of moenomycin $A$ with trifluoroàcetic acid and 2-propanol.4)<smiles>CC1(C)C(O)C(O)C(OC(N)=O)C(O)C1OP(=O)(O)O</smiles>

(22)

Although the rotational value and the magnetical non-equivalency of methylene protons in 1-ethoxyl group were not shown in the literature, ${ }^{5)}$ physical properties of $\mathbf{3}$ prove that $\mathbf{3}$ synthesized here is identical with that obtained from Moenomycin A. The non-equivalency of methylene protons will be attributed to the restricted rotation of $1-O-\mathrm{CH}_{2}$ bond, due to the steric hindrance between 1-ethoxyl and 5 -acetoxyl groups oriented into the inside area of cis-fused five-membered ring. Data of 2 also support this deduction, though $\Delta v$ value of methylene protons is rather smaller. While, the coupling constants $\left(J_{1,2}\right.$ and $J_{2,3}$ ) of 20-22 indicate their ${ }^{4} C_{1}$ (D) conforma- 
tions.

Thus, it was conclusively shown that synthesis of methyl glycoside (20) of 1 can be accomplished by the pathway of $\mathbf{5} \rightarrow \mathbf{9} \rightarrow \mathbf{1 8} \rightarrow \mathbf{1 9} \rightarrow \mathbf{2 0}$ in $73 \%$ overall yield.

\section{Experimental}

General Methods. Melting points were determined with a Mel-Temp hot-plate and are uncorrected. The solutions were evaporated under diminished pressure at a bath temperature not exceeding $50^{\circ} \mathrm{C}$. Specific rotations were measured with Carl Zeiss LEP-Al or JASCO DIP-4 polarimeter, using chloroform as a solvent unless otherwise stated. IR spectra were recorded with Hitachi Model EPL-G2 spectrometer. ${ }^{1} \mathrm{H}$-NMR spectra were taken with JEOL PS-100 spectrometer in chloroform- $d$ unless otherwise stated, using tetramethylsilane as the internal standard. ${ }^{13} \mathrm{C}-\mathrm{NMR}$ data were recorded with JEOL FX-100 spectrometer at $25.16 \mathrm{MHz}$ for the solutions in chloroform- $d$, using $8 \mathrm{~K}$ data points, with proton-noise decoupling. Chemical shifts and coupling constants were recorded in $\delta(\mathrm{ppm})$ and $\mathrm{Hz}$ units, and IR frequencies in $\mathrm{cm}^{-1}$. Column chromatography was performed on silica gel (Wakogel C-200) and preparative TLC on silica gel (Merck type 60).

Methyl 2,3-Di-O-benzyl-6-O-triphenylmethyl- $\alpha$-D-xylo-hexopyranosid-4-ulose (5). A solution of methyl 2,3-di-O-benzyl6 - $O$-trityl- $\alpha$-D-glucopyranoside $\left.{ }^{7}\right)(3 \mathrm{~g}, 4.86 \mathrm{mmol})$ in acetic anhydride $(25 \mathrm{ml})$ and dimethyl sulfoxide $(50 \mathrm{ml})$ was kept overnight at room temperature, poured into ice-water, and then extracted with ether. The usual processing of the extract and purification of the product on a column of silica gel with 15:1 hexane-ethyl acetate gave $\mathbf{5}$ as a syrup in $72 \%(2.15 \mathrm{~g})$ yield. $\left.[\alpha]_{\mathrm{D}}^{2 \mathrm{a}}+47.1^{\circ}(c) 1.2\right)$; IR: $1735(\mathrm{C}=$ O); NMR: $7.55-7.15(\mathrm{~m}, 25 \mathrm{H}, 5 \times \mathrm{Ph}), 4.82(\mathrm{~d}, 1 \mathrm{H}$, $\left.J_{1,2}=3.2, \mathrm{H}-1\right), 4.52-4.98\left(\mathrm{~m}, 4 \mathrm{H}, 2 \times \mathrm{CH}_{2} \mathrm{Ph}\right), 4.36$ (d, $\left.1 \mathrm{H}, J_{2,3}=10.0, \mathrm{H}-3\right), 4.20$ (dd, $\left.1 \mathrm{H}, \mathrm{H}-5\right), 3.78$ (dd, $1 \mathrm{H}$, $\mathrm{H}-2$ ), 3.56 (dd, $\left.1 \mathrm{H}, J_{6,6^{\prime}}=11.0, \mathrm{H}-6\right), 3.53$ (s, $3 \mathrm{H}, \mathrm{OMe}$ ), $3.35\left(\mathrm{dd}, 1 \mathrm{H}, J_{5,6^{\prime}}=7.0, J_{5,6^{\prime}}=10.0, \mathrm{H}-6^{\prime}\right)$. Found: C, $78.53 ; \mathrm{H}, 6.31 \%$. Calcd for $\mathrm{C}_{40} \mathrm{H}_{38} \mathrm{O}_{6}: \mathrm{C}, 78.15 ; \mathrm{H}, 6.23 \%$.

Methyl 2,3-Di-O - benzyl-4-deoxy-4-C-methylene-6-O-triphenylmethyl- $\alpha$-D-xylo-hexopyranoside (6). To an ice-cooled suspension of methyltriphenylphosphonium bromide $(0.6 \mathrm{~g}, 1.68$ mmol) in tetrahydrofuran (THF, $2 \mathrm{ml}$ ) was added butyllithium $(10 \%, 8.7 \mathrm{ml}, 1.36 \mathrm{mmol})$ in hexane with stirring, and to the resulting orange-coloured solution, a solution of $5(1.02 \mathrm{~g}, 1.6 \mathrm{mmol})$ in THF $(9 \mathrm{ml})$ was further added. After stirring the mixture for $30 \mathrm{~min}$, the excess reagent was quenched with acetone, diluted with ether $(20 \mathrm{ml})$, and then filtered. The filtrate was evaporated, and the residual syrup was purified on a column of silica gel with benzene to give 6 as a syrup in $63 \%(640 \mathrm{mg})$ yield. $[\alpha]_{\mathrm{D}}^{23}$ $+40.3^{\circ}$ (c 0.9$)$; IR: $1660(\mathrm{C}=\mathrm{C})$; NMR: $7.70-7.10(\mathrm{~m}$, $25 \mathrm{H}, 5 \times \mathrm{Ph}$ ), $5.20-5.40$ (bs, $2 \mathrm{H}$, methylene), 4.60-5.00 $\left(\mathrm{m}, 5 \mathrm{H}, 2 \times \mathrm{CH}_{2} \mathrm{Ph}\right.$ and $\left.\mathrm{H}-1\right), 4.5-4.2(\mathrm{~m}, 2 \mathrm{H}, \mathrm{H}-3$ and 5), $3.53(\mathrm{~s}, 3 \mathrm{H}, \mathrm{OMe}), 3.30-3.50\left(\mathrm{~m}, 3 \mathrm{H}, \mathrm{H}-6,6^{\prime}\right.$, and 2). Found: $\mathrm{C}, 80.52 ; \mathrm{H}, 6.71 \%$. Calcd for $\mathrm{C}_{41} \mathrm{H}_{40} \mathrm{O}_{5}$ : C, 80.36 ; H, 6.58\%.

Reaction of 4-Uloses with Methyllithium. To a solution of $4(120 \mathrm{mg}, 0.174 \mathrm{mmol})$ in ether $(2 \mathrm{ml})$ cooled with Dry Ice and acetone was added an excess amount of methyllithium $(1.2 \mathrm{M}, 1 \mathrm{ml})$ in ether with stirring, and then the mixture was kept at room temperature for $2 \mathrm{~h}$, poured into saturated ammonium chloride solution. The usual processing of the ether layer and purification of the product on a column of silica gel with $3: 1$ hexane-ethyl acetate gave pure benzyl 2,3-di-O-benzyl-4- $C$-methyl-6-O-triphenylmethyl-
$\alpha$-D-glucopyranoside (7) as a syrup in $58 \%(71 \mathrm{mg}$ ) yield. $[\alpha]_{\mathrm{D}}^{3 \mathrm{3}}+26.8^{\circ}$ (c 1.1); ${ }^{13} \mathrm{C}$ NMR: CMe, $15.79 \mathrm{ppm} ;{ }^{1} \mathrm{H}$ NMR: $7.54-7.12(\mathrm{~m}, 30 \mathrm{H}, 6 \times \mathrm{Ph}), 5.01-4.40(\mathrm{~m}, 6 \mathrm{H}$, $\left.3 \times \mathrm{CH}_{2} \mathrm{Ph}\right), 4.80\left(\mathrm{~d}, 1 \mathrm{H}, J_{1,2}=4.0, \mathrm{H}-1\right), 4.00\left(\mathrm{t}, J_{5,6^{\prime}}=\right.$ 5.8, H-5), 3.84 (d, $1 \mathrm{H}, J_{2,3}=10.6, \mathrm{H}-3$ ), 3.36 (dd, $1 \mathrm{H}, J_{5,6}=$ $5.8, \mathrm{H}-6), 3.36$ (dd, $1 \mathrm{H}, \mathrm{H}-2), 3.25\left(\mathrm{dd}, 1 \mathrm{H}, J_{6, \theta^{\prime}}=11.6\right.$, H- $\left.6^{\prime}\right), 2.32(\mathrm{~s}, 1 \mathrm{H}, \mathrm{OH}), 0.98$ (s, 3H, CMe). Found: C, $79.42 ; \mathrm{H}, 6.65 \%$. Calcd for $\mathrm{C}_{47} \mathrm{H}_{46} \mathrm{O}_{6}: \mathrm{C}, 79.86 ; \mathrm{H}, 6.56 \%$.

A similar reaction of $\mathbf{5}$ with methyllithium gave methyl 2,3-di- $O$-benzyl-4- $C$-methyl-6- $O$ - triphenylmethyl - $\alpha$ - D - glucopyranoside (9) in $95 \%$ yield. $\left.[\alpha]_{\mathrm{D}}^{23}+7.8^{\circ}(c) 1.5\right) ;{ }^{13} \mathrm{C}$ NMR: CMe, $14.92 \mathrm{ppm}$; ${ }^{1} \mathrm{H}$ NMR: $7.60-7.14(\mathrm{~m}, 25 \mathrm{H}$, $5 \times \mathrm{Ph}), 5.03-4.52\left(\mathrm{~m}, 4 \mathrm{H}, 2 \times \mathrm{CH}_{2} \mathrm{Ph}\right), 4.59\left(\mathrm{~d}, 1 \mathrm{H}, J_{1,2}=\right.$ $3.8, \mathrm{H}-1), 3.88$ (dd, $\left.1 \mathrm{H}, J_{2,3}=10.0, \mathrm{H}-2\right), 3.87\left(\mathrm{t}, 1 \mathrm{H}, J_{5,8}=\right.$ $6.0, \mathrm{H}-5$ ), 3.51 (d, $1 \mathrm{H}, \mathrm{H}-3$ ), 3.48 (s, $3 \mathrm{H}, \mathrm{OMe}$ ), 3.39 (d, $2 \mathrm{H}, \mathrm{H}-6$ and $\left.6^{\prime}\right), 2.37$ (s, $\left.1 \mathrm{H}, \mathrm{OH}\right), 1.00$ (s, 3H, CMe). Found: C, 78.29; $\mathrm{H}, 6.78 \%$. Calcd for $\mathrm{C}_{41} \mathrm{H}_{42} \mathrm{O}_{6}$ : C, 78.07; $\mathrm{H}, 6.71 \%$.

Reaction of 4-Uloses with Methylmagnesium Iodide. To a solution of methylmagnesium iodide, prepared from magnesium turnings $(124 \mathrm{mg}, 5.17 \mathrm{mmol})$ and methyl iodide $(1 \mathrm{ml}, 7 \mathrm{mmol})$, in ether $(5 \mathrm{ml})$ chilled with Dry Ice and acetone was added dropwise a solution of $4(187 \mathrm{mg}, 2.72$ $\mathrm{mmol})$ in ether $(2 \mathrm{ml})$ with stirring, and after $2 \mathrm{~h}$, the reaction mixture was poured into saturated aqueous ammonium chloride solution. The usual processing of the ether layer and purification of the product on a column of silica gel with 3:1 hexane-ethyl acetate gave benzyl 2,3-di-O-benzyl4- $C$-methyl-6- $O$-triphenylmethyl- $\alpha$-D-galactopyranoside (8) as a syrup in $84 \%(160 \mathrm{mg})$ yield. $[\alpha]_{\mathrm{D}}^{23}+54.9^{\circ}$ (c 0.8$)$; NMR: $7.64-7.14(\mathrm{~m}, 30 \mathrm{H}, 6 \times \mathrm{Ph}), 5.10-4.25(\mathrm{~m}, 6 \mathrm{H}$, $3 \times \mathrm{CH}_{2} \mathrm{Ph}$ ), 4.98 (d, $1 \mathrm{H}, J_{1,2}=3.5, \mathrm{H}-1$ ), 3.90 (dd, $1 \mathrm{H}$, $\left.J_{2,3}=9.5, \mathrm{H}-2\right), 3.79\left(\mathrm{t}, 1 \mathrm{H}, J_{5,6}=5.0, \mathrm{H}-5\right), 3.59(\mathrm{~d}, 1 \mathrm{H}$, $\mathrm{H}-3$ ), 3.42 (d, $2 \mathrm{H}, \mathrm{H}-6$ and $6^{\prime}$ ), $2.60(\mathrm{~s}, 1 \mathrm{H}, \mathrm{OH}), 1.00$ (s, $3 \mathrm{H}, \mathrm{CMe})$. Found: $\mathrm{C}, 79.74 ; \mathrm{H}, 6.62 \%$. Calcd for $\mathrm{C}_{47}$ $\mathrm{H}_{46} \mathrm{O}_{6} ; \mathrm{C}, 79.86 ; \mathrm{H}, 6.56 \%$.

The reaction of $4(16.6 \mathrm{~g}, 24 \mathrm{mmol})$ with methylmagnesium iodide in ether-THF $(1: 1)$ at refluxing temperature and separation of the products on a flash column of silica gel with 6:1 hexane-ethyl acetate gave 7 and 8 in $35.2 \%(5.98$ g) and $36.3 \%(6.15 \mathrm{~g})$ yields, respectively.

A similar reaction of $5(1.02 \mathrm{~g}, 1.6 \mathrm{mmol})$ with methylmagnesium iodide in ether at $-78^{\circ} \mathrm{C}$ and purification of the products on a flash column of silica gel with $6: 1$ hexaneethyl acetate gave methyl 2,3-di-O-benzyl-4- $C$-methyl-6-Otriphenylmethyl- $\alpha$-D-galactopyranoside (10) as a syrup in $84 \%$ (850 mg) yield. $[\alpha]_{\mathrm{D}}^{2 \pi}+18.2^{\circ}$ (c 1.0$)$; NMR: $7.68-$ $7.16(\mathrm{~m}, 25 \mathrm{H}, 5 \times \mathrm{Ph}), 5.06-4.56(\mathrm{~m}, 5 \mathrm{H}, \mathrm{H}-1$ and $2 \times$ $\mathrm{CH}_{2} \mathrm{Ph}$ ), 3.90 (dd, $\left.1 \mathrm{H}, J_{1,2}=3.0, \mathrm{H}-2\right), 3.70\left(\mathrm{t}, 1 \mathrm{H}, J_{5,8}=\right.$ 4.0, H-5), 3.54 (d, $1 \mathrm{H}, J_{2,3}=9.5, \mathrm{H}-3$ ), 3.52 (s, 3H, OMe), 3.41 (d, $2 \mathrm{H}, \mathrm{H}-6$ and $6^{\prime}$ ), 0.98 (s, 3H, CMe). Found: C, $77.82 ; \mathrm{H}, 6.83 \%$. Calcd for $\mathrm{C}_{41} \mathrm{H}_{42} \mathrm{O}_{6}: \mathrm{C}, 78.07 ; \mathrm{H}, 6.71 \%$.

When the reaction of $\mathbf{5}$ with methylmagnesium iodide in ether is carried out at room temperature, separation of the products on a flash column of silica gel with 6:1 hexaneethyl acetate gave $\mathbf{9}$ and $\mathbf{1 0}$ in 29 and $64 \%$ yields, respectively.

Reaction of 4-Uloses and Diazomethane. To a solution of 4 (138 $\mathrm{mg}, 2.0 \mathrm{mmol})$ in ethanol $(50 \mathrm{ml})$ was added dropwise a solution of diazomethane $(4.0 \mathrm{mmol})$ in ether (20 $\mathrm{ml}$ ) at $0^{\circ} \mathrm{C}$. After keeping the mixture at room temperature for $12 \mathrm{~h}$, the solution was evaporated to give a syrup. Separation of the syrup on a preparative TLC gave a ringexpanded product, benzyl 2,3-di-O-benzyl-5-deoxy-7-O-triphenylmethyl- $\alpha$-D- $x y l o$-heptaseptanosid-4-ulose $(13)$ and corresponding spiro epoxide, benzyl 4,4'-anhydro-2,3-di-Obenzyl-4- $C$-hydroxymethyl-6- $O$ - triphenylmethyl - $\alpha-\mathrm{D}$ - gluco- 
pyranoside (11) in 60 and $20 \%$ yields, respectively.

11: syrup, $[\alpha]_{\mathrm{D}}^{23}+56.4^{\circ}(c$ 2.8); NMR: $7.6-7.1(\mathrm{~m}$, $30 \mathrm{H}, 6 \times \mathrm{Ph}), 5.0-4.40(3 \times \mathrm{ABq}, 6 \mathrm{H}, J=11.0$ and 12.0 , $\left.3 \times \mathrm{CH}_{2} \mathrm{Ph}\right), 4.97\left(\mathrm{~d}, 1 \mathrm{H}, J_{1,2}=3.6, \mathrm{H}-1\right), 4.64\left(\mathrm{t}, 1 \mathrm{H}, J_{5,6}=\right.$ $4.0, \mathrm{H}-5$ ), 4.20 (d, $1 \mathrm{H}, J_{2,3}=10.0, \mathrm{H}-3$ ), 3.55 (dd, $1 \mathrm{H}, \mathrm{H}-2$ ), $3.04\left(\mathrm{~d}, 2 \mathrm{H}, \mathrm{H}-6\right.$ and $\left.6^{\prime}\right), 3.06$ and $2.43(\mathrm{ABq}, 2 \mathrm{H}, J=5.0$, epoxy $\mathrm{CH}_{2}$ ). Found: C, 80.38; $\mathrm{H}, 6.33 \%$. Calcd for $\mathrm{C}_{47} \mathrm{H}_{44} \mathrm{O}_{8}: \mathrm{C}, 80.09 ; \mathrm{H}, 6.29 \%$.

Compound 13 could not be completely purified, but the NMR and IR spectra could be analyzed. IR: $1720(\mathrm{C}=0)$; NMR: $7.50-7.10(\mathrm{~m}, 30 \mathrm{H}, 6 \times \mathrm{Ph}), 5.03\left(\mathrm{~d}, 1 \mathrm{H}, J_{1,2}=1.8\right.$, $\mathrm{H}-1), 4.95-4.43\left(\mathrm{~m}, 7 \mathrm{H}, 3 \times \mathrm{CH}_{2} \mathrm{Ph}\right.$ and $\left.\mathrm{H}-6\right), 4.18$ (d, $1 \mathrm{H}, J_{2,3}=8.0, \mathrm{H}-3$ ), 3.74 (dd, $\left.1 \mathrm{H}, \mathrm{H}-2\right), 3.35-3.00(\mathrm{~m}$, $2 \mathrm{H}, \mathrm{H}-7$ and $\left.7^{\prime}\right) 2.78$ and $2.50\left(\mathrm{dABq}, 2 \mathrm{H}, J_{\mathrm{A}, \mathrm{B}}=14.0\right.$, $J_{5,6}=11.0, J_{5^{\prime}, 6}=4.0, \mathrm{H}-5$ and $\left.5^{\prime}\right)$.

A similar reaction of $\mathbf{5}$ and diazomethane and the separation of the products on prepative TLC gave a ring-expanded product, methyl 2,3-di-O-benzyl-5-deoxy-7-O-triphenylmeth $y \mathrm{l}-\alpha$-D- $x y l o$-heptaseptanosid-4-ulose (14), and the corresponding spiro epoxide, methyl 4,4'-anhydro-2,3-di- $O$-benzyl-4$C$-hydroxymethyl-6- $O$ - triphenylmethyl - $\alpha$ - D - glucopyranoside (12) 60 and $15 \%$ yields, respectively.

12: syrup; $[\alpha]_{\mathrm{D}}^{23}+17.8^{\circ}$ (c 0.8$)$; NMR: 7.56-7.14 $(\mathrm{m}, 25 \mathrm{H}, 5 \times \mathrm{Ph}), 4.91-4.59\left(\mathrm{~m}, 4 \mathrm{H}, 2 \times \mathrm{CH}_{2} \mathrm{Ph}\right), 4.69$ (d, $\left.1 \mathrm{H}, J_{1,2}=3.2, \mathrm{H}-1\right), 4.36\left(\mathrm{t}, 1 \mathrm{H}, J_{5,6}=4.2, \mathrm{H}-5\right), 4.18$ (d, $1 \mathrm{H}, J_{2,3}=10.0, \mathrm{H}-3$ ), 3.64 (s, $3 \mathrm{H}, \mathrm{OMe}$ ), 3.58 (dd, $1 \mathrm{H}$, $\mathrm{H}-2), 3.07\left(\mathrm{~d}, 2 \mathrm{H}, \mathrm{H}-6\right.$ and $\left.6^{\prime}\right), 3.02$ and $2.42(\mathrm{ABq}, 2 \mathrm{H}$ $J=5.0$, epoxy $\mathrm{CH}_{2}$ ). Found: $\mathrm{C}, 78.01 ; \mathrm{H}, 6.58 \%$. Calcd for $\mathrm{C}_{41} \mathrm{H}_{40} \mathrm{O}_{6}: \mathrm{C}, 78.32 ; \mathrm{H}, 6.41 \%$.

14: syrup, $\left.[\alpha]_{\mathrm{D}}^{3 \mathrm{~s}}+19.5^{\circ}(c) 0.9\right)$; IR: $1720(\mathrm{C}=\mathrm{O})$; NMR: $7.50-7.15(\mathrm{~m}, 25 \mathrm{H}, 5 \times \mathrm{Ph}), 4.81\left(\mathrm{~d}, 1 \mathrm{H}, J_{1,2}=2.0\right.$ $\mathrm{H}-1), 4.82-4.03\left(2 \times \mathrm{ABq}, 4 \mathrm{H}, 2 \times \mathrm{CH}_{2} \mathrm{Ph}\right), 4.05-4.35(\mathrm{~m}$ $2 \mathrm{H}, J_{2,3}=9.0, \mathrm{H}-3$ and 6$), 3.71(\mathrm{dd}, 1 \mathrm{H}, \mathrm{H}-2), 3.42(\mathrm{~s}, 3 \mathrm{H}$ $\mathrm{OMe}$ ), 3.40-2.98 (m, 2H, H-7 and $7^{\prime}$ ), 2.79 and 2.55 (dABq, $2 \mathrm{H}, J_{\mathrm{A}, \mathrm{B}}=14,0, J_{5,8}=10.0, J_{5^{\prime}, 6}=2.0, \mathrm{H}-5$ and $5^{\prime}$ ). Found: C, $78.30 ; \mathrm{H}, 6.38 \%$. Calcd for $\mathrm{C}_{41} \mathrm{H}_{40} \mathrm{O}_{6}: \mathrm{C}, 78.32 ; \mathrm{H}$, $6.41 \%$.

Reduction of Spiro Epoxides with Lithium Aluminium Hydride. To a solution of $\mathbf{1 1}(200 \mathrm{mg}, 0.28 \mathrm{mmol})$ in THF $(20 \mathrm{ml})$ was added lithium aluminium hydride (LAH, $50 \mathrm{mg}, 1.3$ $\mathrm{mmol}$ ) and then the mixture was refluxed for $2 \mathrm{~h}$. The excess hydride was decomposed with water, and then filterd. The water layer was extracted with chloroform. The combined extract was washed with water, dried, and evaporated to give a syrupy $\mathbf{7}$ in quantitative yield, which was identical with that obtained by the reaction of $\mathbf{4}$ and methyllithium at $-78^{\circ} \mathrm{C}$.

A similar reduction of $12(200 \mathrm{mg})$ in THF $(20 \mathrm{ml})$ as above gave 9 in quantitative yield, which was identical with that obtained by the reaction of $\mathbf{5}$ and methyllithium at $-78^{\circ} \mathrm{C}$.

Reduction of 15 (200 mg) in THF (20 ml) as above gave 10 in quantitative yield, which was identical with that obtained by the reaction of $\mathbf{5}$ and methylmagnesium iodide at $-78^{\circ} \mathrm{C}$.

$\mathrm{m}$-Chloroperoxybenzoic Acid Oxidation of 6 .

A solution of crude $6(500 \mathrm{mg}, 0.82 \mathrm{mmol})$ and $m$-chloroperoxybenzoic acid $(630 \mathrm{mg}, 3.65 \mathrm{mmol})$ in dichloroethane $(50 \mathrm{ml})$ was stirred overnight at room temperature, and then washed successively with aqueous sodium hydroxide $(0.1 \mathrm{M})$, water, saturated sodium chloride, and water, and then dried and evaporated. The residual syrup was separated on a column of silica gel with 5:1 hexane-ethyl acetate to give methyl 4,4'-anhydro-2,3-di- $O$-benzyl - 4 - $C$-hydroxymethyl- 6 - $O$ - triphenylmethyl- $\alpha$-D-glucopyranoside $(12)$ and $-\alpha$-D-galactopyranoside (15) as syrups each in $21.3 \%$ (110 mg) yield. Physical constants of 12 were indentical with the authentic sample that was derived from the reaction of $\mathbf{5}$ and diazomethane. 15: $[\alpha]_{\mathrm{D}}^{22}+4.4^{\circ}(c \quad 0.8)$ : NMR: $7.60-7.10(\mathrm{~m}, 25 \mathrm{H}, 5 \times$ $\mathrm{Ph}$ ), $4.66\left(\mathrm{~d}, 1 \mathrm{H}, J_{1,2}=3.4 \mathrm{H}-1\right), 4.53-4.98(\mathrm{~m}, 4 \mathrm{H}, 2 \times$ $\mathrm{CH}_{2} \mathrm{Ph}$ ), 4.14 (d, 1H, H-3), 4.12 (t, $1 \mathrm{H}, \mathrm{H}-5$ ), 3.73 (dd $\left.1 \mathrm{H}, J_{2,3}=10.0, \mathrm{H}-2\right), 3.41$ (s, $\left.3 \mathrm{H}, \mathrm{OMe}\right), 3.26(\mathrm{dd}, 1 \mathrm{H}$, $\left.J_{5,6^{\prime}}=5.2, \mathrm{H}-6^{\prime}\right), 2.99\left(\mathrm{dd}, 1 \mathrm{H}, J_{5,6}=6.2, J_{6,6^{\prime}}=10.0, \mathrm{H}-6\right.$ ), 2.89 and $2.74\left(\mathrm{ABq}, 2 \mathrm{H}, J=5.0\right.$, epoxy $\left.\mathrm{CH}_{2}\right)$. Found: C, $78.51 ; \mathrm{H}, 6.62 \%$. Calcd for $\mathrm{C}_{41} \mathrm{H}_{40} \mathrm{O}_{6}: \mathrm{C}, 78.32 ; \mathrm{H}$, $6.41 \%$.

De-O-tritylation of 4-C-Methyl Derivatives (7-9). A solution of $7(1.47 \mathrm{~g}, 2.05 \mathrm{mmol})$ in acetic acid $(70 \%, 30$ ml) was heated at $100^{\circ} \mathrm{C}$ for $5 \mathrm{~h}$, filtered at room temperature, and then evaporated. The resulting syrup was purified on a column of silica gel with $3: 1$ hexane-ethyl acetate gave pure benzyl 2,3-di-O-benzyl-4- $C$-methyl- $\alpha$-D-glucopyranoside $(\mathbf{1 6})$ as a syrup in $98 \%(1.1 \mathrm{~g})$ yield. $[\alpha]_{\mathrm{n}}^{\mathrm{s}}+88.7^{\circ}$ (c 1.1); NMR: $7.6-6.8(\mathrm{~m}, 15 \mathrm{H}, 3 \times \mathrm{Ph}), 5.02-4.36(\mathrm{~m}$, $6 \mathrm{H}, 3 \times \mathrm{CH}_{2} \mathrm{Ph}$ ), 4.81 (dd, $1 \mathrm{H}, J_{5,6}=3.5, \mathrm{H}-6$ ), 4.78 (d, $\left.1 \mathrm{H}, J_{1,2}=4.0, \mathrm{H}-1\right), 4.74\left(\mathrm{t}, 1 \mathrm{H}, J_{5,6^{\prime}}=3.5, \mathrm{H}-5\right), 4.59$ (dd, $\left.1 \mathrm{H}, J_{6,8}=7.0, \mathrm{H}-6^{\prime}\right), 3.71(\mathrm{~d}, 1 \mathrm{H}, \mathrm{H}-3), 3.38\left(\mathrm{dd}, 1 \mathrm{H}, J_{2,3}=\right.$ 10.0, H-2), 2.92 (bs, $1 \mathrm{H}, \mathrm{OH}), 1.14(\mathrm{~s}, 3 \mathrm{H}, \mathrm{CMe})$. Found: C, $72.11 ; \mathrm{H}, 7.07 \%$. Calcd for $\mathrm{C}_{28} \mathrm{H}_{32} \mathrm{O}_{6}: \mathrm{C}, 72.39 ; \mathrm{H}$, $6.94 \%$.

In a similar manner, de- $O$-tritylation of $8(1.29 \mathrm{~g}, 1.8$ $\mathrm{mmol}$ ) and purification of the product on a column of silica gel with 3:1 hexane-ethyl acetate gave benzyl 2,3-di- $O$ benzyl-4- $C$-methyl- $\alpha$-D-galactopyranoside $(\mathbf{1 7})$ as a syrup in $96 \%(0.96 \mathrm{~g})$ yield. $[\alpha]_{\mathrm{0}}^{3 \mathrm{~s}}+101^{\circ} \quad(c 1.1)$, NMR: 7.6$7.1(\mathrm{~m}, 15 \mathrm{H}, 3 \times \mathrm{Ph}), 5.1-4.4\left(\mathrm{~m}, 6 \mathrm{H}, 3 \times \mathrm{CH}_{2} \mathrm{Ph}\right), 4.88$ (d, $\left.1 \mathrm{H}, J_{1,2}=4.0, \mathrm{H}-\mathrm{l}\right), 3.94-3.54(\mathrm{~m}, 4 \mathrm{H}, \mathrm{H}-3,5$ and 6), $3.42\left(\mathrm{dd}, 1 \mathrm{H}, J_{2,3}=10.0, \mathrm{H}-2\right), 2.26(\mathrm{~s}, 1 \mathrm{H}, \mathrm{OH}), 1.18$ (s, 3H, CMe). Found: C, 72.23; H, 7.15\%. Calcd for $\mathrm{C}_{28} \mathrm{H}_{32} \mathrm{O}_{6}:$ C, 72.39; $\mathrm{H}, 6.94 \%$.

In a similar manner, de- $O$-tritylation of $9(6.3 \mathrm{~g}, 10 \mathrm{mmol})$ and purification of the products gave methyl 2,3-di-O-benzyl4- $C$-methyl- $\alpha$-D-glucopyranoside (18) in $90 \%$ (3.5 g) yield, together with a small amount of its 6-acetate as syrups.

18: $[\alpha]_{D}^{23}+31.4^{\circ}(c$ 0.9); NMR: 7.6-7.1 and 5.10-4.52 $\left(\mathrm{m}, 14 \mathrm{H}, 2 \times \mathrm{CH}_{2} \mathrm{Ph}\right), 4.61\left(\mathrm{~d}, 1 \mathrm{H}, J_{1,2}=4.0, \mathrm{H}-1\right), 4.0-$ $3.5(\mathrm{~m}, 5 \mathrm{H}, \mathrm{H}-2,3,4$ and 6$), 3.40(\mathrm{~s}, 3 \mathrm{H}, \mathrm{OMe}), 3.36$ (bs, $1 \mathrm{H}, \mathrm{OH}), 1.18(\mathrm{~s}, 3 \mathrm{H}, \mathrm{CMe})$. Found: C, $67.77 ; \mathrm{H}, 7.10 \%$. Calcd for $\mathrm{C}_{22} \mathrm{H}_{28} \mathrm{O}_{6}$ : C, 68.02; $\mathrm{H}, 7.27 \%$.

6-Acetate showed the following ${ }^{1} \mathrm{H}-\mathrm{NMR}$ deta: $7.6-7.1$ and $5.16-4.52\left(\mathrm{~m}, 14 \mathrm{H}, 2 \times \mathrm{CH}_{2} \mathrm{Ph}\right), 4.59\left(\mathrm{~d}, 1 \mathrm{H}, J_{1,2}=\right.$ $4.0, \mathrm{H}-1$ ), 4.38 (dd, $1 \mathrm{H}, J_{5,6}=2.0, J_{6,6^{\prime}}=12.0, \mathrm{H}-6$ ), 4.11 (dd, $\left.1 \mathrm{H}, J_{5,6^{\prime}}=6.0, \mathrm{H}-6^{\prime}\right), 3.75\left(\mathrm{~d}, 1 \mathrm{H}, J_{2,3}=9.5, \mathrm{H}-3\right.$ ), 3.49 (dd, $1 \mathrm{H}, \mathrm{H}-2$ ), 3.40 (s, 3H, OMe), 2.16 (bs, 1H, OH), 2.05 (s, 3H, Ac), 1.17 (s, 3H, CMe).

Methyl 4-C-Methyl- $\alpha$-D-glucopyranoside (19). The usual hydrogenation of $18(3.9 \mathrm{~g}, 10 \mathrm{mmol})$ in ethanol in the presence of palladium-charcoal $(10 \%)$ gave 19 as a syrup in quantitative $(2.08 \mathrm{~g})$ yield. $[\alpha]_{\mathrm{D}}^{33}+100^{\circ}(c 0.8, \mathrm{MeOH})$; NMR $\left(\mathrm{CD}_{3} \mathrm{OD}\right): 4.67\left(\mathrm{~d}, 1 \mathrm{H}, J_{1,2}=4.0, \mathrm{H}-1\right), 3.96-3.10$ (m, 5H, H-2,3,5, and 6), $3.43(\mathrm{~s}, 3 \mathrm{H}, \mathrm{OMe}), 1.07(\mathrm{~s}, 3 \mathrm{H}$, $\mathrm{CMe}$ ). Found: C, 46.50; H, 7.68\%. Calcd for $\mathrm{C}_{8} \mathrm{H}_{16} \mathrm{O}_{6}$ : C, $46.15 ; \mathrm{H}, 7.75 \%$

Methyl 4-C-Methyl- $\alpha$-D-glucuronic Acid (20). Gaseous oxygen was bubbled into a solution of $19(1.0 \mathrm{~g}, 4.8 \mathrm{mmol})$ in water at $90^{\circ} \mathrm{C}$ for $40 \mathrm{~h}$ in the presence of platinum-carbon $(10 \%, 0.3 \mathrm{~g})$, and $\mathrm{pH}$ of the reaction mixture was maintained about 8.0 with sodium hydrogencarbonate. After 19 has disappeared on TLC, the mixture was filtered, and treated with Amberlite (IR-120) and the filtrate was evaporated to give 20 as a syrup in $86 \%(917 \mathrm{mg})$ yield. Physical data of $\mathbf{2 0}$ were shown in Table 2. Found: C, 42.97; $\mathrm{H}, 6.01 \%$. Calcd for $\mathrm{C}_{8} \mathrm{H}_{14} \mathrm{O}_{7}$ : C, $43.24 ; \mathrm{H}, 6.35 \%$.

Ethyl 2,5-Di-O-acetyl-4-C-methyl- $\beta$-D - glucofuranosidurono- $6,3-$ 
lactone (3) and Methyl 2,3-Di-O-acetyl-4-C-methyl- $\alpha$-D-glucopyranosiduronic Acid Ethyl Ester (21). A solution of 20 $(500 \mathrm{mg}, 2.25 \mathrm{mmol})$ in ethanolic hydrogen chloride $(0.1$ M) was refluxed for $16 \mathrm{~h}$, and then evaporated to give a syrup. Acetic anhydride $(2 \mathrm{ml})$ was added to a solution of the syrup in pyridine $(2 \mathrm{ml})$. After keeping overnight at room temperature, the mixture was evaporated together with ethanol to give a syrup. Separation of the syrup on a preparative TLC (benzene-acetone 8:1) gave 21 mp $99-101^{\circ} \mathrm{C}$ (from ether-hexane); Found: C, 50.27; $\mathrm{H}$, $6.61 \%$. Calcd for $\mathrm{C}_{14} \mathrm{H}_{22} \mathrm{O}_{9}: \mathrm{C}, 50.29 ; \mathrm{H}, 6.63 \%$ \} and 3 (syrup; Found: $\mathrm{C}, 51.84 ; \mathrm{H}, 6.26 \%$. Calcd for $\mathrm{C}_{13} \mathrm{H}_{18} \mathrm{O}_{8}$ : $\mathrm{C}, 51.65 ; \mathrm{H}, 6.00 \%)$ in $55 \%(414 \mathrm{mg})$ and $28 \%(190 \mathrm{mg})$ yields, respectively. Physical constants of 3 and 21 were shown in Table 2.

Ethyl 4-C-Methyl- $\beta$-D-glucofuranosidurono-6,3-lactone (2). A similar ethanolysis of 21 (334 $\mathrm{mg}, 1.0 \mathrm{mmol}$ ) as above for $3 \mathrm{~d}$ gave syrupy 2 (Found: $\mathrm{C}, 49.47 ; \mathrm{H}, 6.50 \%$. Calcd for $\mathrm{C}_{9} \mathrm{H}_{14} \mathrm{O}_{6}: \mathrm{C}, 49.54 ; \mathrm{H}, 6.47 \%$.) in quantitative (218 $\mathrm{mg}$ ) yield. Physical data of 2 were shown in Table 2.

The authors thank Mr. Y. Nakamura for measurements of ${ }^{13} \mathrm{C}-\mathrm{NMR}$ spectra.

\section{References}

1) Part XXVIII. J. Yoshimura, K. Hara, M. Yamaura, K. Mikami, and H. Hashimoto, Bull. Chem. Soc. Jpn., 55, 933 (1982).

2) W. A. Slusarchyk, Biotechnol. Bioeng., 13, 399 (1971); V. P. Welzel, F.-J. Witteler, D. Müller, and W. Riemer, Angew. Chem., Int. Ed. Engl., 93, 130 (1981).

3) Y. van Heijenoort, M. Derrien, and J. van Heijenoort, F. E. B. S. Letters, 89, 141 (1978); P. E. Linett and J. L.
Strominger, Antimicrob. Angents Chemother., 4, 231 (1973).

4) F.-J. Witteler, P. Welzel, H. Duddeck, G. Höfle, W. Riemer, and H. Budzikiewicz, Tetrahedron Lett., 1979, 3493.

5) N. Langenfeld and P. Welzel, Tetrahedron Lett., 1978, 1833.

6) M. Matsuzawa, K. Kubo, H. Kodama, M. Funabashi, and J. Yoshimura, Bull. Chem. Soc. Jpn., 54, 2169 (1981).

7) R. E. Wing, C. L. Collins, and J. N. Bemiller, J. Chromatogr., 32, 303 (1968).

8) M. Miljkovic, M. Gligorijevic, T. Satoh, and D. Miljkovic, J. Org. Chem., 39, 1379 (1974); M. Miljkovic, M. Gligorijevic, T. Satoh, D. Glishin, and R. D. Pitcher, ibid., 39, 3847 (1974).

9) M. Matsuzawa, K. Sato, T. Yasumori, and J. Yoshimura, Bull. Chem. Soc. Jpn., 54, 3505 (1981).

10) K. Sato, M. Matsuzawa, K. Ajisaka, and J. Yoshimura, Bull. Chem. Soc. Jpn., 53, 189 (1980).

11) K. Sato and J. Yoshimura, Carbohydr. Res., 73, 75 (1979); Bull. Chem. Soc. Jpn., 51, 2116 (1978).

12) J. Yoshimura, K. Sato, and M. Funabashi, Bull. Chem. Soc. Jpn., 52, 2630 (1979).

13) R. W. Mills, R. D. H. Murray, and R. A. Raphael, J. Chem. Soc., D, 1971, 555; R. Slack and W. A. Waters, J. Chem. Soc., 1948, 1666; Y. Besace, I. Marszak, and J. Maisse, Bull. Soc. Chim. Fr., 1971, 2275.

14) W. R. Brasen and C. R. Hauser, J. Org. Chem., 18, 808 (1953); H. I. E. Zimmermann and J. English, Jr., J. Am. Chem. Soc., 76, 2285 (1954).

15) H. Weidmann and H. K. Zimmerman, Ann., 684, 226 (1965); J. Yoshimura, T. Sato, and H. Ando, Bull. Chem. Soc. Jpn., 42, 2352 (1969).

16) C. L. Stevens and S. H. Czernecki, Carbohydr. Res., 63, 307 (1978). 